\title{
Tradisi Luru Duit di Indramayu
}

\author{
Sulistyo Budiarto ${ }^{1 *}$, Koentjoro ${ }^{1}$ \\ ${ }^{1}$ Fakultas Psikologi Universitas Gadjah Mada \\ *st.budiarto@gmail.com
}

\begin{abstract}
Child prostitution in Indramayu has been done for generations and has been formed into a tradition. Prostitution in Indramayu known as the luru duit meaning work for money or livelihood. Referring to the meaning of luru duit, shows that prostitution has been accepted as a form of work, similar to another forms of work. This study aims to identify the factors that influence luru duit phenomenon. Research uses the Etno-phenomenological method. Collecting data through interviews, observation and documents. The result shows luru duit is a planned behavior, it can be seen from three factors interacting. Internal factors include a positive attitude on materialism, the motivation to follow the views of others, the perception of ease on doing luru duit. External factors include micro and macro level. At the micro level includes the ability to access opportunities, namely the lack of jobs and poor education. At the macro level includes social situations, for example, early marriage and divorce as well as the situation of a long history of forming Bong village as the sender area of women for prostitution. The phenomenon of luru duit facilitates by the presence of the figure of the channel. Chanel as a liaison has amode in two ways, namely using violence method, coercion and fraud. The second way is to utilize the victim and the victim's parents desire for a better life in a way to seduce with money.
\end{abstract}

Keywords: Child, Prostitution, Luru Duit

\begin{abstract}
Abstrak. Aktivitas melacurkan anak di desa Bong, Kabupaten Indramayu sudah menjadi tradisi yang dilakukan turun temurun hingga saat ini. Tradisi ini dikenal dengan istilah luru duit yang bermakna bekerja untuk mencari uang. Penelitian ini bertujuan untuk mengidentifikasi faktor-faktor yang mempengaruhi tumbuh suburnya fenomena luru duit tersebut. Penelitian dilakukan dengan metode etnofenomenologi. Pengumpulan data melalui wawancara, observasi dan dokumentasi. Hasil penelitian menunjukan terdapat faktor-faktor yang saling berinteraksi dalam mempengaruhi keputusan seseorang untuk luru duit. Faktor internal mencakup di dalamnya sikap positif terhadap luru duit, kepatuhan anak kepada orang tua, pengalaman, peran pelaku duit yang telah sukses sehingga memperkuat niat seseorang untuk melakukan luru duit. Selanjutnya, terdapat peran perantara atau channel yang aktif bergerak untuk mencari perempuan di desa untuk luru duit. Faktor eksternal mencakup budaya kawin cerai, pandangan mengenai nilai anak, sikap positif masyarakat, serta kontrol sosial yang rendah.
\end{abstract}

Kata kunci: Anak, Luru duit, Prostitusi.

Di Indonesia, saat ini, fenomena anak dilacurkan kondisinya semakin mengkhawatirkan. Banyak anak yang dimobilisasi oleh pihak-pihak tertentu yang memiliki kuasa ke sejumlah daerah untuk dijadikan objek seks orang dewasa. Keberadaan mereka dapat dengan mudah ditemui di lokasi- 
lokasi transaksi seks. Sebagian lokasi tersebut bersifat terbuka, seperti di lokalisasi. Namun banyak juga lokasi yang sifatnya tertutup, seperti karaoke, salon plus dan kafe. Terkait hal itu, hingga saat ini, belum ada angka pasti yang secara akurat menggambarkan jumlah anak- anak yang terlibat dalam industri seks.

Indramayu merupakan salah satu wilayah pengirim utama perempuan muda untuk dilacurkan tersebut. Hal demikian terlihat dari beberapa hasil riset sebelumnya, yang menunjukan bahwa pekerja seks di beberapa lokalisasi berasal dari wilayah Indramayu. Sebagai contoh, hasil kajian Budi (2015) menemukan bahwa 62 dari 150 orang pekerja seks yang tercatat di Saritem, Bandung berasal dari Indramayu.

Selain itu, pekerja seks di kota Batam juga banyak yang berasal dari daerah Indramayu. Di kota yang berbatasan dengan Singapura tersebut, perempuan asal Indramayu cukup tenar popularitasnya. Mereka digemari oleh pelanggan karena kemolekan tubuh mereka. Pelanggan mereka tidak hanya laki-laki lokal saja namun datang dari banyak negara (Wibowo, 2014).

Desa Bong merupakan salah satu desa di Indramayu yang dikenal sebagai pengirim perempuan untuk dilacurkan. Hal ini telah menjadi tradisi yang dilakukan secara turun temurun. Kebiasaan itu dikenal dengan istilah luru duit, yang bermakna bekerja untuk mencari uang/nafkah. Luru duit berasal dari bahasa Jawa, luru berarti mencari, dan duit yang bermakna uang (materi/harta). Studi yang dilakukan oleh Pattilima (2005) secara tajam menggambarkan luru duit sebagai suatu bagian dari budaya masyarakat setempat, karena ia sudah dilakukan hampir semua komunitas.

Luru duit dilatarbelakangi oleh motif untuk memiliki kekayaan serta meningkatkan status sosial, khususnya oleh orang tua di sana. Dukungan, serta peran serta orang tua, merupakan salah satu faktor yang melanggengkan kebiasaan tersebut. Bagi orang tua, luru duit bukan sebauh aib untuk keluarga, namun mereka justru bangga apabila anaknya berhasil dalam luru duit. Terkait hal itu, Zuchrowi (2003) menyebut bahwa bagi orang tua di sana, anak perempuan dianggap sebagai sebagai aset keluarga. Oleh karena itu, sejak masa kanak-kanak, mereka sudah ditanamkan nilai untuk tidak malu menjadi pekerja seks. Karena apabila berhasil, mereka akan mampu merubah garis nasib, sekaligus menyenangkan orang tuanya. Orang justru dikatakan "bodoh" manakala mereka tidak mau menjual anak perempuanya. Karena sikap orang tua yang demikian, sebagian anak anak perempuan yang tidak mau mengikuti kemauan orang tuanya, mereka memilih kabur. 
Luru duit dan latar belakang sejarah

Tidak tulisan sejarah yang menjelaskan mengenai munculnya luru duit desa Bong, tempat dimana penelitian ini dilakukan. Meski demikian, ada yang mengkaitkan fenomena kebiasaan perempuan yang luru duit di desa Bong dengan legenda berdirinya Indramayu. Legenda tersebut mengisahkan tentang seorang pemimpin kerajaan Bagelen yang ingin meluaskan wilayah kekuasaanya tanpa melalui peperangan. Pemimpin Bagelen tersebut kemudian mengajukan sebuah pinangan kepada bupati Sumedang. Ia mengutus seorang laki-laki yang menyamar sebagai perempuan untuk diperistri oleh Bupati Sumedang. Singkat cerita, pada waktu itu, Bupati Sumedang menyetujui pinangan, dengan mahar sebagian tanah wilayah kekuasaan Sumedang yang sudah ditentukan kedua belah pihak. Akan tetapi, pada saat menjelang malam pertama, perempuan tersebut berubah menjadi laki-laki kembali. Bupati Sumedang terkejut dan marah karena sudah ditipu: istri tidak didapat dan justru kehilangan tanah kekuasaan. Karena kacewa, perjanjian pemberian tanah kekuasaan sebagai mahar perkawinan sudah disepakati dan tidak mungkin dibatalkan, sehingga bupati Sumedang pun akhirnya mengeluarkan kutukan, bahwa anak-keturunan raja tersebut akan berperilaku seperti lakilaki yang menyamar perempuan sebelumnya, yaitu mereka akan menjadi perempuan penggoda ataupun waria, seperti calon istri yang menipunya.

Di sisi lain, dari sudut pandang sejarah, tumbuhnya desa Bong sebagai daerah pemasok utama perempuan muda untuk tujuan dilacurkan juga dipengaruhi peristiwa sejarah yang berlangsung di Indramayu. Kegiatan prostitusi di wilayah itu sudah berlangsung sejak zaman kerajaan, yang lebih dikenal dengan istilah perseliran. Desa Gabus Wetan di Indramayu merupakan daerah tujuan raja-raja Cirebon untuk mencari selir (Hull, 1997).

Pada masa kolonial Belanda, praktek demikian juga masih terus berlangsung. Pada masa itu, praktek prostitusi dilakukan untuk melayani nafsu para serdadu Belanda serta orangorang Eropa. Praktik-praktik ini dilatarbelakangi adanya pelarangan perkawinan antar ras oleh budaya masing-masing penjajah. Dampak dari adanya pelarangan perkawinan antar ras ini menginisiasi adanya perdagangan perempuan pribumi kepada masyarakat penjajah untuk tujuan komersial. Dengan menjadi simpanan pejabat kolonial Belanda, para Nyai memiliki status sosial tinggi di mata masyarakat.

Pada masa pendudukan penjajah Jepang, praktek-praktek prostitusi di Indramayu diyakini terlihat semakin memprihatinkan, serta mengarah pada 
perbudakan. Pada masa itu, banyak dari perempuan di wilayah Indramayu dibawa ke kota lain, atau dari desa ke kota, dengan jerat penipuan berupa tawaran pekerjaan yang cukup baik. Sedangkan untuk anak-anak perempuan yang masih sekolah, mereka ditawari untuk bersekolah di kota atau di Tokyo. Banyak perempuan yang tertarik dengan tawaran itu, lalu mereka dibawa dan ditampung ke daerahdaerah sekitar pelabuhan Semarang, Surabaya dan Jakarta (Tanjung Priok). Namun dalam kenyataanya, mereka tidak disekolahkan, namun justru dipaksa untuk melayani serdadu Jepang secara rutin dan terjadwal (Hull, 1997).

Dalam praktek prostitusi pada masa lalu itu, mereka yang masih berusia anak-anak juga sudah umum untuk dijadikan pelaku atau objek seksual. Baik praktek perseliran pada masa kerajaan, maupun per-nyai-an pada masa kolonialisme, umumnya mereka menggunakan anak-anak sebagai objek komoditas seks. Ketika dijadikan selir untuk para raja, atau nyai untuk orang Eropa, mereka biasanya telah akil balik dan usianya direntang antara 14 hinga 18 tahun.

Paparan di atas menunjukan bahwasanya anak perempuan sebagai komoditas untuk dilacurkan telah dimulai ketika masa-masa feodal, dan mengalami perkembangan dari masa ke masa. Dewasa ini, seiring dengan meningkatnya kemakmuran, terlihat bahwa tingkat rekreasi seksual dan keinginan untuk mendapatkan variasi seksual juga meningkat. Sebagai akibatnya, bentuk variasi seks yang unik menjadi pilihan yang menarik ketika uang bukan lagi masalah. Hal itu dimungkinkan karena secara naluriah manusia senantiasa mengejar kenikmatan dan tingkat kenikmatan seseorang senantiasa meningkat seiring dengan bertambahnya kemakmuran (Soares, 2011).

Fenomena anak dilacurkan di Bong semakin rumit, ketika zaman mulai berubah menuju era globalisasi. Aspirasi materialisme (Koentjoro, 2004), gaya hidup konsumerisme (Suyanto, 2012), dan pergaulan bebas (Hwang, 2003) memiliki pengaruh yang kuat dalam mendorong pelibatan anak dalam prostitusi. Di luar itu, terlihat bahwa prostitusi anak menjadi jalan pintas untuk memenuhi kebutuhan material. Studi yang dilakukan Muflichah (2009) menunjukan bahwa pada masyarakat desa aspek-aspek budaya dan ekonomi turut mendorong terjadinya traficking anak. Riset tersebut juga mengungkapkan bahwa keinginan yang tinggi untuk dihargai merupakan salah satu karakter individual penyebab timbulnya trafficking.

\section{Karakteristik Luru Duit}

Luru duit di Indramayu terlihat sudah menjadi bagian dari budaya masyarakat setempat. Dalam arti, ia sudah dilakukan oleh hampir sebagian besar anggota 


\section{SULISTYO \& KOENTJORO}

masyarakat. Sebagaimana dijelaskan sebelumnya, luru duit adalah sebuah tindakan yang bertujuan memperoleh kesugihan (kekayaan) yang menjadi ukuran capaian status sosial masyarakat dengan jalan menjual diri. Kekayaan tersebut mereka yakini dapat menjamin masa depan yang lebih baik, serta mampu membahagiakan keluarga, terutama orang tuanya. Status sosial di masyarakat pun akan terangkat apabila memiliki kekayaan. Dengan memiliki kekayaan serta status sosial tersebut, mereka berharap akan mendapatkan penghargaan dari orangorang sekitar dan memperoleh kebanggaan diri.

Salah satu ciri yang paling menonjol dalam usaha untuk mencapai kekayaan tersebut adalah adanya pelibatan anak-anak dalam luru duit. Aktivitas luru duit itu dilakukan ketika anak-anak masih berusia remaja, yakni pada rentang antara usia 1216 tahun. Mayoritas dari perempuan yang melakukan luru duit hanya menyelesaikan pendidikan formalnya setingkat Sekolah Menengah Pertama (SMP). Bahkan banyak di antara mereka yang hanya mengenyam pendidikan setingkat Sekolah Dasar (SD). Orang tua memiliki peran yang cukup besar pada pelibatan anak dalam luru duit tersebut.

Karakteristik khas lain dalam luru duit dapat dilihat dari latar belakang status pernikahan perempuan pelakunya. Meskipun masih berusia belia, mayoritas dari mereka sudah bersatus cerai dari pasangannya. Perstiwa itu mendorong munculnya istilah RCTI, yang berarti janda kecil asal Indramayu. Kawin cerai pada usia anak-anak diduga merupakan proses permulaan bagi perempuan sebelum melakukan luru duit.

Di luar itu, pernikahan dini juga terlihat menjadi bagian awal proses seorang anak perempuan akan melakukan luru duit. Biasanya mereka diputuskan sekolahnya, dinikahkan terlebih dahulu, baru setelah itu diceraikan secepatnya. Selain disebabkan paksaan orangtua, pernikahan dini juga disebabkan oleh kehamilan karena pergaulan bebas. Alasan lain dari pernikahan dini adalah untuk membayar hutang, karena orang tua terlilit hutang dan tidak bisa membayar, sehingga anak dijadikan jaminan dengan cara menikahkannya. Gambaran demikian ditegaskan oleh Pattilima (2005) bahwa masyarakat pada penelitian ini dilakukan, anak perempuan lazimnya dinikahkan cepat-cepat, diceraikan cepat-cepat, selanjutnya luru duit.

Mengacu pada pemaparan di atas, nampak bahwa luru duit merupakan tradisi untuk melacurkan anak yang berlangsung di Indramayu. Anak-anak tersebut menjalani hidup di dunia prostitusi sebagai sebuah pekerjaan. Melihat realitas demikian, peneliti telah mengkaji secara lebih mendalam tentang dinamika tradisi luru duit di Indramayu, yang pada prakteknya merupakan aktivitas untuk melacurkan anak tersebut. Artikel ini merupakan publikasi hasil riset tersebut. Dalam artikel ini, penulis akan memaparkan mengenai dinamika psikologis yang berlangsung pada anak-anak dalam menginternalisasi luru duit sebagai bagian dari pekerjaan dan peran 
keluarga, termasuk sosialisasi tradisi luru duit kepada anak-anak tersebut. Secara khusus, penulis akan menjelaskan faktor-faktor yang berpengaruh bagi perkembangan luru duit desa Bong.

\section{Metode}

Penelitian ini dilakukan di desa Bong, yang dikenal sebagai daerah yang menjadi sumber pengirim anak perempuan untuk luru duit. Penelitian ini menggunakan metode ethnophenomenology. Adapun tehnik pengumpulan data yang dilakukan menggunakan wawancara dan pengamatan langsung. Informan utama penelitian ini adalah dua orangtua yang memiliki anak yang luru duit, dua perempuan yang melakukan luru duit, serta ditambah dua perantara (channel) dan dua tokoh masyarakat sebagai informan pendukung.

\section{Hasil}

Untuk melakukan identifikasi desa Bong sebagai desa sumber perempuan luru duit menjadi tantangan tersendiri bagi penulis. Hal demikian terjadi karena sikap tertutup dari aparat pemerintahan setempat. Ada dua hal yang melatarbelakangi ketertutupan tersebut. Pertama, hal itu dapat memberi citra buruk bagi desa. Kedua, hal itu terkait dengan kinerja jajaran aparat pemerintahan daerah dalam penanggulangan permasalahan tersebut.
Persoalan prostitusi sudah muncul sejak lama tetapi hingga penelitian ini dilakukan berbagai program dan kebijakan belum dapat menghentikan fenomena tersebut. Kekhawatiran yang muncul adalah adanya pendapat bahwa aparat setempat tidak becus dalam menanggulangi fenomena prostitusi yang ada di wilayah mereka.

\section{Latar belakang luru duit}

Sebagaimana dijelaskan sebelumnya, tradisi luru duit di Indramayu memiliki akar sejarah yang panjang. Ia juga menyangkut pandangan, nilai, dan norma budaya setempat. Secara khusus, pada masa kini, ada beberapa pihak yang memfasilitas atau terlibat dalam praktek luru duit tersebut, sebagaimana yang penulis paparkan berikut.

Orang tua

Informan utama orangtua dalam penelitian ini adalah dua orangtua yang memiliki anak perempuan yang menjalani luru duit. Mereka merupakan warga yang tinggal dan menetap di desa Bong. Informan utama orangtua adalah Ibu Dar. Ibu Dar hanya memiliki seorang anak perempuan tunggal, yang luru duit di Tanah Abang Jakarta. Nama anak tersebut adalah Sen. Ia sudah berusia 24 tahun dan telah empat kali berangkat luru duit. Sebelum berangkat, Sen pernah dinikahkan dengan seorang pemuda desa, tetapi pernikahan tersebut tidak berlangsung lama. 
Meskipun mendukung penuh anaknya untuk luru duit, Ibu Dar merasa menyesal, karena anaknya dianggap tidak berhasil membawa rejeki. Hasil dari luru duit di Jakarta hanya cukup untuk merenovasi rumah dan modal untuk berdagang nasi goreng. Ibu Dar mengaku bahwa keberangkatan anaknya luru duit ke Jakarta tidak membawa hasil. Sebagai buktinya, ia masih merasa kesusahan dan harus banting tulang bekerja untuk keperluan sehari-sehari. Salah satu contohnya, rumahnya yang ia tinggali hingga saat ini belum berdinding bata. Untuk keperluan hidup sehari-sehari, Ibu Dar dan suaminya juga masih menggantungkan hidupnya dari hasil berdagang nasi goreng serta menjadi buruh tani di kala masa tanam dan panen. Berikut pernyataan Ibu Dar menggambarkan pandangannya tersebut :

"Berangkat juga tidak ada hasilnya. Sudah empat kali berangkat, itu tidak ada hasilnya. Ya, anaknya tidak ada rejekinya. Tidak ada rejekinya. Cuma untuk makan saja". Karena dianggap tidak berhasil dalam luru duit di Jakarta, Sen akhirnya disuruh pulang untuk membantu Ibu Dar. Meskipun demikian, Ibu Dar memiliki keinginan agar Sen luru duit lagi. Ia berharap, di kesempatan berikutnya, Sen berhasil membawa rejeki bagi Ibu Dar. Ketika Sen berhasil dalam luru duit, maka ia tidak akan lagi berjualan nasi goreng. Selain itu, uangnya dapat dipergunakan untuk keperluan yang lain.

"Ya maunya sih ada yang bawa kerja. Itu aja inginnya. Sama kaya temen itu. Sekarang ada TKW. Dulu mah belum ada kerja jadi TKW. Temennya kerja kaya gitu. Mungkin Sen berfikir, 'Saya anaknya orang yang tidak kaya'. Temen-teman yang anaknya orang kaya juga pada begitu. Belum ada rejeki. Belum ada milik. Jadiya kaya gini saja."

Data yang dikumpulkan menunjukan latar belakang Ibu Dar yang mendukung serta memberi dorongan pada anak perempuanya untuk berangkat luru duit di Jakarta. Terdapat dua faktor internal, yakni keinginan dan harapan pada anak sebagai sumber rejeki bagi dirinya. Sedangkan faktor eksternalnya adalah karena mengikuti kebiasaan tetangga yang sudah terlebih dahulu berangkat luru duit dan berhasil. Gambaran lebih utuh mengenai luru duit oleh Ibu Dar tersebut dapat dilihat pada Tabel 1. 
Tabel 1

Proses yang Melatarbelakangi Ibu Dar Mendorong Anaknya untuk luru Duit

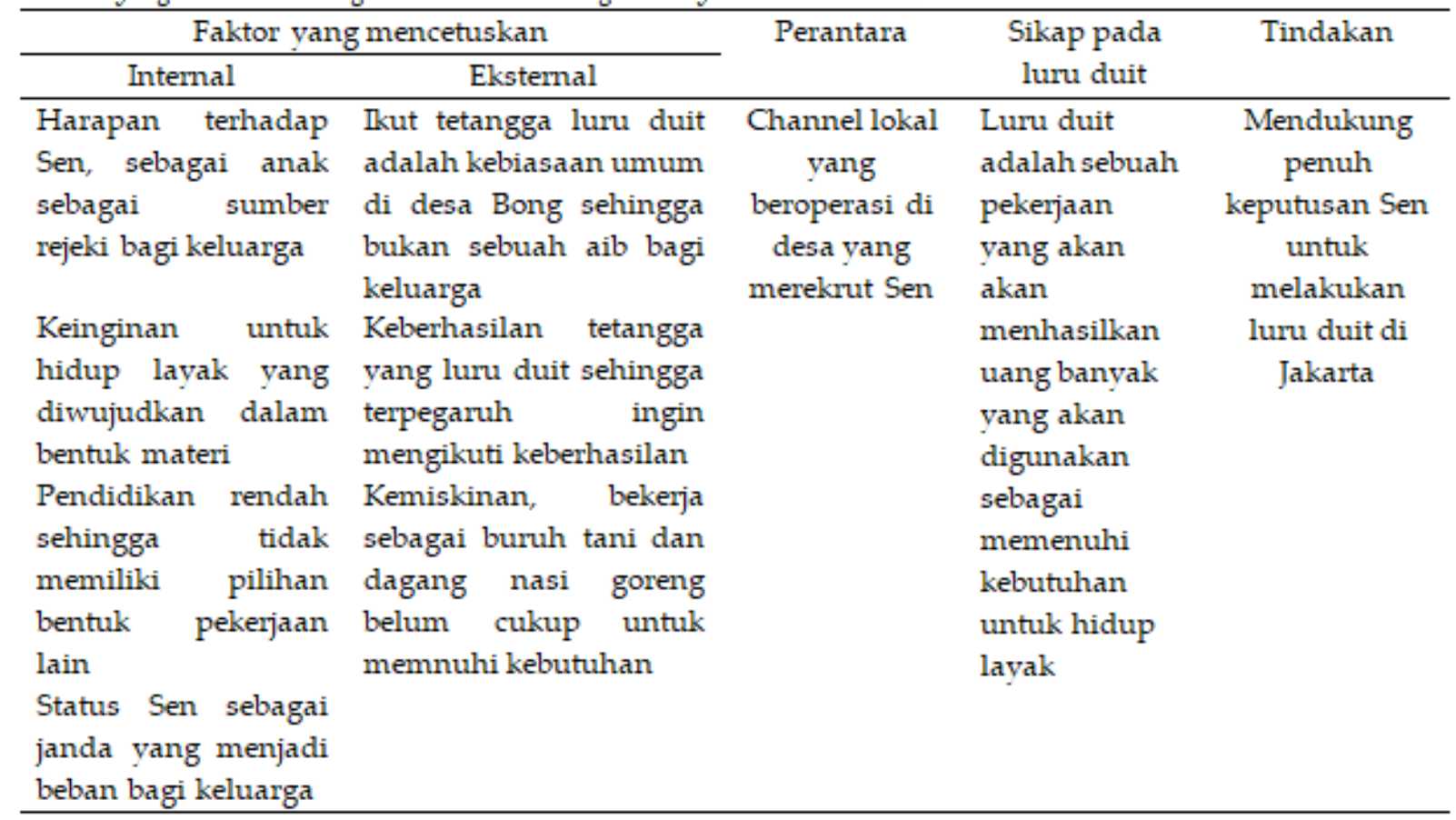

Informan utama orangtua yang kedua dalam penelitian ini adalah Pak Moh. Pak Moh adalah seorang laki-laki berusia 55 tahun. Ia seorang duda yang pernah menikah sebanyak tiga kali. Setelah Pak Moh bercerai, ia tinggal di rumah ibunya bersama anak perempuanya, Nu. Seorang anak lakilaki, namanya $\mathrm{Ka}$, ikut tinggal bersamanya karena ditinggal istrinya bekerja di Taiwan. Ka adalah anak lakilaki Pak Moh. Ia telah menikah dan memiliki seorang anak. Istrinya saat itu sedang pergi bekerja di Taiwan. Sedang $\mathrm{Nu}$, semenjak pernikahanya gagal, sudah empat bulan memutuskan pergi luru duit.

Kondisi kemiskinan yang dialami oleh Pak Moh menjadikan alasan Pak Moh mendukung keputusan $\mathrm{Nu}$, anak perempuannya, memutuskan untuk berangkat luru duit. $\mathrm{Nu}$, belum lama luru duit di café remang-remang daerah Cikampek. Menurut Pak Moh, anaknya mungkin merasa malu dan merasa kasihan melihat kondisi ayahnya yang pasca bercerai dari ibunya harus hidup dalam kondisi miskin.

$$
\text { "Iya gitulah, riwayat hidup saya. Ya, }
$$
emang saya ini sedang kolaps bener. Akhirnya anak saya gitu. Tapi ya memang ada orangtua yang dari awal memang menginginkan anaknya berangkat. Tapi kalo saya mah, sikon saya seperti ini. Anak itu punya sedikit rasa malu untuk seperti itu. Apa kasihan sama orangtuanya, terus akhirnya berangkat."

Tidak ada aktivitas pekerjaan yang dilakukan oleh Pak Moh setiap harinya. Meskipun secara fisik sebenarnya ia masih cukup kuat untuk bekerja, tiap 
hari Pak Moh mengisi waktu dengan sekedar bermain bola sodok (bilyard) di rumah milik tetangganya. Untuk memenuhi kebutuhan sehari-hari, ia mengandaakan kiriman dari Nu. Selain untuk memenuhi kebutuhan seharihari, ia juga mempergunakan kiriman itu untuk membeli tanah. Tanah seluas 17 bata ( 1 bata $=14$ meter persegi) tersebut ia beli dengan cara dicicil. Sebagai uang muka, ia telah membayar sebanyak lima juta rupiah.

"Pulang terakhir 10 hari yang lalu.

Ya cuman sehari. Ngasih panjeran tanah, lima juta. Di Karang Palu, Dekat pesantren sana. Ada tanah 15 bata. Satu batanya itu 2 juta. Satu bata 14 meter persegi. Itu kan baru panjer. Punya saudara juga. Kasihan saya sih. Ya bayarnya pipil-pipil. Ya anak saya kasihan aja orangtuanya nggak punya tanah. Ya, yang penting murahlah. Punya saudara. Daripada dijual ke orang lain."

Gambaran tersebut menunjukan Pak Moh memposisikan $\mathrm{Nu}$ sebagai mesin "anjungan tunai mandiri (ATM)", sumber uang untuk memenuhi kebutuhan dirinya. Pak Moh beralasan bahwa kondisi sakit yang diderita saat ini, akibat kecelakaan dua tahun lalu, menyebabkan dirinya tidak bisa bekerja untuk mencari nafkah sendiri. Akibatnya, ia hidup dalam kemiskinan, tidak mampu memenuhi kebutuhan hidup sehari-hari, apalagi menghidupi anaknya. Sehingga, satu-satunya cara adalah bergantung hidup dari anaknya. Gambaran proses latar belakang yang mendorong Pak Moh mendorong anaknya untuk luru duit tersebut dapat dilihat pada Tabel 2.

Tabel 2.

Proses yang Melatarbelangi Pak Moh Mendorong Anaknya Luru Duit

\begin{tabular}{|c|c|c|c|c|}
\hline \multicolumn{2}{|c|}{ Faktor Pemicu } & \multirow[t]{2}{*}{ Perantara } & \multirow{2}{*}{$\begin{array}{l}\text { Sikap pada } \\
\text { Luru Duit }\end{array}$} & \multirow[t]{2}{*}{ Keputusan/tindakan } \\
\hline Internal & Eksternal & & & \\
\hline $\begin{array}{l}\text { Kemalasan dalam diri } \\
\text { Pak Moh sehingga } \\
\text { lebih memilih } \\
\text { bergantung pada } \\
\text { anak. } \\
\text { Memandang anak } \\
\text { sebagai "ATM" bagi } \\
\text { dirinya. } \\
\text { Status janda } \\
\text { menyebabkan Nu } \\
\text { tidak ingin } \\
\text { membebani orangtua }\end{array}$ & $\begin{array}{l}\text { Kemiskinan } \\
\text { karena sakit } \\
\text { sehingga merasa } \\
\text { tidak bisa kerja. }\end{array}$ & $\begin{array}{l}\text { Peran teman } \\
\text { yang telah } \\
\text { luru duit } \\
\text { sebagai } \\
\text { perantara. }\end{array}$ & $\begin{array}{l}\text { Luru duit } \\
\text { merupakan } \\
\text { cara yang } \\
\text { relatif mudah } \\
\text { dalam } \\
\text { mendapatkan } \\
\text { uang untuk } \\
\text { meningkatkan } \\
\text { kesejahteraan. }\end{array}$ & $\begin{array}{l}\text { Mendorong anaknya } \\
\text { untuk luru duit. }\end{array}$ \\
\hline
\end{tabular}




\section{Perempuan Luru Duit}

Informan lain dalam penelitian ini adalah dua orang perempuan yang menjadi pelaku luru duit. Berikut paparan mereka mengenai pandangan dan pengalaman mereka sebagai pelaku luru duit.

a. Ri, mantan pelaku luru duit di Jakarta

Perjalanan Ri melakukan luru duit diawali ketika menginjak usia delapan belas tahun. Kala itu, Ri baru saja bercerai dengan suaminya, yang ia menikah dengannya karena dijodohkan oleh orangtua. Pernikahan ini digagas oleh orang tuanya dengan maksud agar Ri kembali tinggal di rumah orang tuanya. Namun pernikahan tersebut hanya bertahan selama kurang dari satu bulan. Ri tidak mau dikekang di rumah.

$\mathrm{Ri}$ ingin mencari kebebasan, sehingga pada akhirnya ia berangkat ke Jakarta. Ia bekerja di hotel M, sebuah hotel berbintang ternama di Jakarta. Di sana, ia bekerja sebagai pekerja seks.
Para tamunya datang dari golongan menengah atas berkantong tebal. Bisnis prostitusi di hotel M dilakukan terselubung dengan kemasan tempat spa, sauna, massage (pijat) dan gym (kebugaran). Tamu-tamu yang dilayani $\mathrm{Ri}$ biasanya adalah para pengusaha dan pebisnis yang sedang melakukan negoisasi tentang bisnis atau para pejabat negara. Tidak jarang juga terdapat tamu orang luar negeri yang sedang berada di Indonesia. Jasa Ri dipakai sebagai bagian dari negoisasi dan hiburan untuk memuluskan kontrak bisnis para pengusaha tersebut.

Ri terlibat perilaku luru duit didorong keinginan mengikuti gaya hidup teman sebayanya. Mereka mampu membeli bermacam barang baru yang sedang tren. Sementara, apabila dirinya, sebagai seorang SPG, ia hanya bergaji kecil yang hanya cukup untuk memenuhi keperluan sehari-hari. Gambaran pengalaman $\mathrm{Ri}$ tersebut terlihat pada Tabel 3.

Tabel 3 .

Proses yang Melatarbelakangi Ri Melakukan Luru Duit

\begin{tabular}{|c|c|c|c|c|}
\hline \multicolumn{2}{|c|}{ Faktor pemicu } & \multirow[t]{2}{*}{ Perantara } & \multirow{2}{*}{$\begin{array}{c}\text { Sikap pada } \\
\text { Luru Duit }\end{array}$} & \multirow[t]{2}{*}{ Keputusan/tindakan } \\
\hline Internal & Eksternal & & & \\
\hline $\begin{array}{l}\text { Harapan Ingin hidup } \\
\text { sejahtera. } \\
\text { Tujuan ingin bisa } \\
\text { memiliki serta } \\
\text { mengikuti tren dan } \\
\text { gaya hidup modern. } \\
\text { Status sebagai janda } \\
\text { dan tidak ingin } \\
\text { membebani orangtua }\end{array}$ & $\begin{array}{l}\text { Pergaulan } \\
\text { dengan teman } \\
\text { sebaya yang } \\
\text { terlibat praktek } \\
\text { prostitusi }\end{array}$ & $\begin{array}{l}\text { Peran teman } \\
\text { yang telah luru } \\
\text { duit sebagai } \\
\text { perantara }\end{array}$ & $\begin{array}{l}\text { Luru duit } \\
\text { merupakan cara } \\
\text { yang mudah } \\
\text { dalam } \\
\text { mendapatkan } \\
\text { uang untuk } \\
\text { membeli barang } \\
\text { dan biaya gaya } \\
\text { hidup }\end{array}$ & $\begin{array}{l}\text { Mengikuti temanya } \\
\text { menjadi pekerja seks } \\
\text { di hotel M Jakarta }\end{array}$ \\
\hline
\end{tabular}


b. Sa, mantan pelaku luru duit di Tanjung Pinang

Sa adalah perempuan yang tumbuh besar dalam keluarga yang miskin. Ayahnya bekerja serabutan di sebuah rumah makan sedangkan ibunya sehari-hari berkutat mengurusi rumah tangga. Sa merupakan anak tertua dari tiga bersaudara. Sa sudah malang melintang luru duit di pulau Sumatra dan Jakarta. Lika-liku perjalanan hidup Sa penuh dengan cerita pilu. Pengalaman-pengalaman tersebut justru membuat Sa semakin mantap memilih pekerjaan sebagai pekerja seks sebagai jalan hidupnya.

Proses luru duit Sa dimulai ketika ia berusia 16 tahun, selepas bercerai dengan suami pertamanya. Suatu ketika, seorang tamu karaoke mengajak Sa untuk bekerja di luar Jawa, sebagai pembantu rumah tangga. Terdesak dengan keadaan ekonomi, Sa menerima tawaran tersebut. Namun pada saat telah tiba di lokasi tujuan, ternyata Sa justru dijual kepada germo di kota Tanjung Pinang dan dijerat untuk melunasi hutang kasbon.

"Setelah 3 hari aku minta pulang, tapi sama bos ditahan, katanya yang nganter aku itu ngambil duit. Temen aku itu. Sekitar satu juta setengah. Nah, kalau saya mau pulang, saya harus bayarin uang itu dulu. Trus katanya lagi, uang itu buat ibu aku. Boro -boro. Orang dia gak kenal Ibu aku. Terus, akhirnya aku usaha. Dapat orang China. Waktu itu, aku utang dulu, buat bayar ke bos karena aku pengen pulang banget ya. Di sana, aku cuma dapat seminggu".

Tabel 4.

Proses yang Melatarbelakangi Sa Melakukan Luru Duit

\begin{tabular}{|c|c|c|c|c|}
\hline \multicolumn{2}{|c|}{ Faktor Pemicu } & \multirow{2}{*}{ Perantara } & \multirow{2}{*}{$\begin{array}{l}\text { Sikap terhadap } \\
\text { Luru Duit }\end{array}$} & \multirow{2}{*}{ Keputusan } \\
\hline Internal & Eksternal & & & \\
\hline $\begin{array}{l}\text { Keinginan untuk } \\
\text { membantu orang tua. }\end{array}$ & $\begin{array}{l}\text { Hutang kasbon } \\
\text { pada germo yang } \\
\text { dimiliki yang } \\
\text { harus dilunasi. }\end{array}$ & $\begin{array}{l}\text { Peran } \\
\text { chanel, } \\
\text { yang } \\
\text { membujuk }\end{array}$ & $\begin{array}{l}\text { Luru duit } \\
\text { merupakan } \\
\text { satu-satunya } \\
\text { pekerjaan yang }\end{array}$ & $\begin{array}{l}\text { Melakukan luru duit } \\
\text { sebagai tulang } \\
\text { punggung keluarga } \\
\text { besar Sa }\end{array}$ \\
\hline $\begin{array}{l}\text { Pendidikan rendah, } \\
\text { tidak memiliki } \\
\text { ketrampilan yang } \\
\text { memadai. }\end{array}$ & $\begin{array}{l}\text { Hidup dalam } \\
\text { keluarga miskin } \\
\text { dengan orang tua } \\
\text { yang } \\
\text { berpenghasilan } \\
\text { tidak tetap. }\end{array}$ & $\begin{array}{l}\text { Sa dengan } \\
\text { mengiming- } \\
\text { imingi } \\
\text { pekerjaan } \\
\text { di kota. }\end{array}$ & $\begin{array}{l}\text { bisa dilakukan } \\
\text { untuk bertahan } \\
\text { hidup } \\
\text { meningkatkan } \\
\text { kesejahteraan } \\
\text { dan } \\
\text { menghidupi } \\
\text { keluarga. }\end{array}$ & \\
\hline $\begin{array}{l}\text { Statusnya sebagai } \\
\text { janda yang tidak ingin } \\
\text { menjadi beban dalam } \\
\text { keluarga. }\end{array}$ & & & & \\
\hline
\end{tabular}


Peran channel sebagai perantara

Peran perantara dalam mencari perempuan untuk luru duit memegang peranan penting. Sangat jarang di desa Bong ada seorang perempuan yang secara mandiri mendatangi germo untuk bekerja di kafenya, baik yang di dalam kota maupun luar kota. Umumnya, mereka difasilitasi oleh seorang perantara yang menghubungkan mereka dangan germo tempatnya bekerja. Di Desa Bong, perantara ini umumnya dikenal sebagai channel.

Berdasarkan pengalaman subjek dan informan tahu, di desa Bong terdapat dua pola channel dalam bekerja merekrut perempuan baru. Berikut uraian mengenai pola dan bentuk channel memengaruhi perempuan untuk luru duit di desa Bong.

Pada Tabel 5 dapat dilihat bahwa channel memiliki peran yang dominan dalam memengaruhi dan memfasilitasi seorang perempuan untuk luru duit. Channel merupakan penghubung antara persediaan di desa dan lokasi permintaan di kota. Terdapat dua pola channel bekerja, yaitu secara aktif dan secara pasif. Channel yang bekerja secara

Tabel 5 .

Proses Pereknutan. Bentuk dan Pola Perantara (channul) Bekerja

\begin{tabular}{|c|c|c|c|c|}
\hline \multirow{2}{*}{ Subjek } & \multirow{2}{*}{ Proses } & \multirow{2}{*}{ Bentuk Channel } & \multicolumn{2}{|c|}{ Pola Channel Bekerja } \\
\hline & & & Aktif & Pasif \\
\hline Tbu dar & $\begin{array}{l}\text { Sen anak Ibu Dar } \\
\text { mendapatkan } \\
\text { informasi dan } \\
\text { ajakan dari } \\
\text { temanya yang } \\
\text { sudah luru duit }\end{array}$ & $\begin{array}{l}\text { Channel yang } \\
\text { membawa Sen } \\
\text { adalah teman } \\
\text { mereka sendiri } \\
\text { yang bekerja di } \\
\text { pada seorang }\end{array}$ & $\begin{array}{l}\text { Sebagai perekrut, dengan } \\
\text { mengajak dan memberikan } \\
\text { gambaran bentuk kerja serta } \\
\text { penghasilan yang akan } \\
\text { didapatkan. } \\
\text { Sebagai pengirim dengan }\end{array}$ & \\
\hline Pak Moh & $\begin{array}{l}\text { Nu anak Pak Moh } \\
\text { diajak temanya } \\
\text { untuk bekerja di } \\
\text { kafe Cikampek. }\end{array}$ & germo. & $\begin{array}{l}\text { mengantar hingga ke tempat } \\
\text { germo. } \\
\text { Ditugaskan oleh bosnya } \\
\text { sehingga apabila membawa } \\
\text { orang baru akan } \\
\text { mendapatkan imbalan. }\end{array}$ & \\
\hline Ri & $\begin{array}{l}\text { Ri terpikat oleh } \\
\text { gaya hidup } \\
\text { temanya yang } \\
\text { menjadi pekerja } \\
\text { seks. }\end{array}$ & $\begin{array}{l}\text { Chanel yang } \\
\text { membawa Ri } \\
\text { adalah teman } \\
\text { dekatnya yang } \\
\text { sudah luru duit }\end{array}$ & & $\begin{array}{l}\text { Menunjukan gaya } \\
\text { hidup yang } \\
\text { menjadi panutan } \\
\text { bagi Ri }\end{array}$ \\
\hline Sa & $\begin{array}{l}\text { Sa dan } \\
\text { keluarganya } \\
\text { dibujuk dengan } \\
\text { diiming-imingi } \\
\text { pekerjaan di } \\
\text { Jakarta dengan } \\
\text { gaji yang } \\
\text { lumayan. }\end{array}$ & $\begin{array}{l}\text { Seorang perantara } \\
\text { murni yang } \\
\text { bekerja di desa } \\
\text { yang memiliki } \\
\text { jaringan dengan } \\
\text { bos. }\end{array}$ & $\begin{array}{l}\text { Sebagai perekrut, membujuk } \\
\text { dengan memberi fasilitas } \\
\text { hutang (kasbon). } \\
\text { Pengirim mengirim } \\
\text { perempuan dari desa ke } \\
\text { tujuan. } \\
\text { Memiliki uang operasiona, } \\
\text { fee, dan bonus. }\end{array}$ & \\
\hline
\end{tabular}


pasif diperankan oleh perempuan yang berhasil luru duit, mereka ini merupakan panutan bagi komunitasnya. Sedangkan channel yang aktif diperankan oleh orang lokal, bisa jadi tetangga mereka sendiri yang merupakan kepanjangan tangan germo di kota.

\section{Perkawinan dan perceraian}

Salah satu ciri khas yang menonjol pada perempuan yang luru duit di desa Bong adalah statusnya calon pelakunya yang menjanda. Pernikahan anak di desa Bong dilatari oleh cara pandang orang tua terhadap anak perempuan. Di desa tersebut, anak perempuan dianggap sebagai beban apabila belum menikah. Pernikahan anak merupakan cara untuk mengurangi beban bagi orangtua tersebut.

Pada kasus Sa, untuk meringankan beban ekonomi keluarga, melalui pernikahan anak dijadikan komoditas untuk dipertukarkan dengan pelunasan Tabel 6 .

Latar belakang pernikahan dan perceraian

\begin{tabular}{|c|c|c|c|c|c|}
\hline Informan & $\begin{array}{l}\text { Usia } \\
\text { Menikah }\end{array}$ & $\begin{array}{l}\text { Jumlah } \\
\text { pernikahan }\end{array}$ & $\begin{array}{c}\text { Usia } \\
\text { Pernikahan }\end{array}$ & $\begin{array}{l}\text { Alasan } \\
\text { Bercerai }\end{array}$ & Latar belakang \\
\hline $\mathrm{Ri}$ & 18 tahun & 2 & 1 bulan & $\begin{array}{l}\text { Ditinggal } \\
\text { pergi } \\
\text { suami }\end{array}$ & $\begin{array}{l}\text { Diatur oleh orang tua, karena } \\
\text { merasa bahwa } \mathrm{Ri} \text { sudah cukup } \\
\text { dewasa. Khawatir dan malu apabila } \\
\text { punya anak yang sudah dewasa dan } \\
\text { bekerja tapi belum menikah. }\end{array}$ \\
\hline $\mathrm{Sa}$ & 16 tahun & 3 & 3 bulan & $\begin{array}{l}\text { Ditinggal } \\
\text { pergi } \\
\text { suami }\end{array}$ & $\begin{array}{l}\text { Diatur oleh orang tua, dilatari motif } \\
\text { ekonomi. Orang tua memiliki } \\
\text { hutang pada seseorang. Agar } \\
\text { hutang keluarganya dapat lunas } \\
\text { atau berkurang, ia dinikahkan. }\end{array}$ \\
\hline $\mathrm{Na}$ & 16 tahun & 1 & 5 bulan & $\begin{array}{l}\text { Ditinggal } \\
\text { pergi } \\
\text { suami }\end{array}$ & $\begin{array}{l}\text { Orang tua merasa malu karena } \mathrm{Na} \\
\text { hamil tidak memiliki suami. }\end{array}$ \\
\hline
\end{tabular}




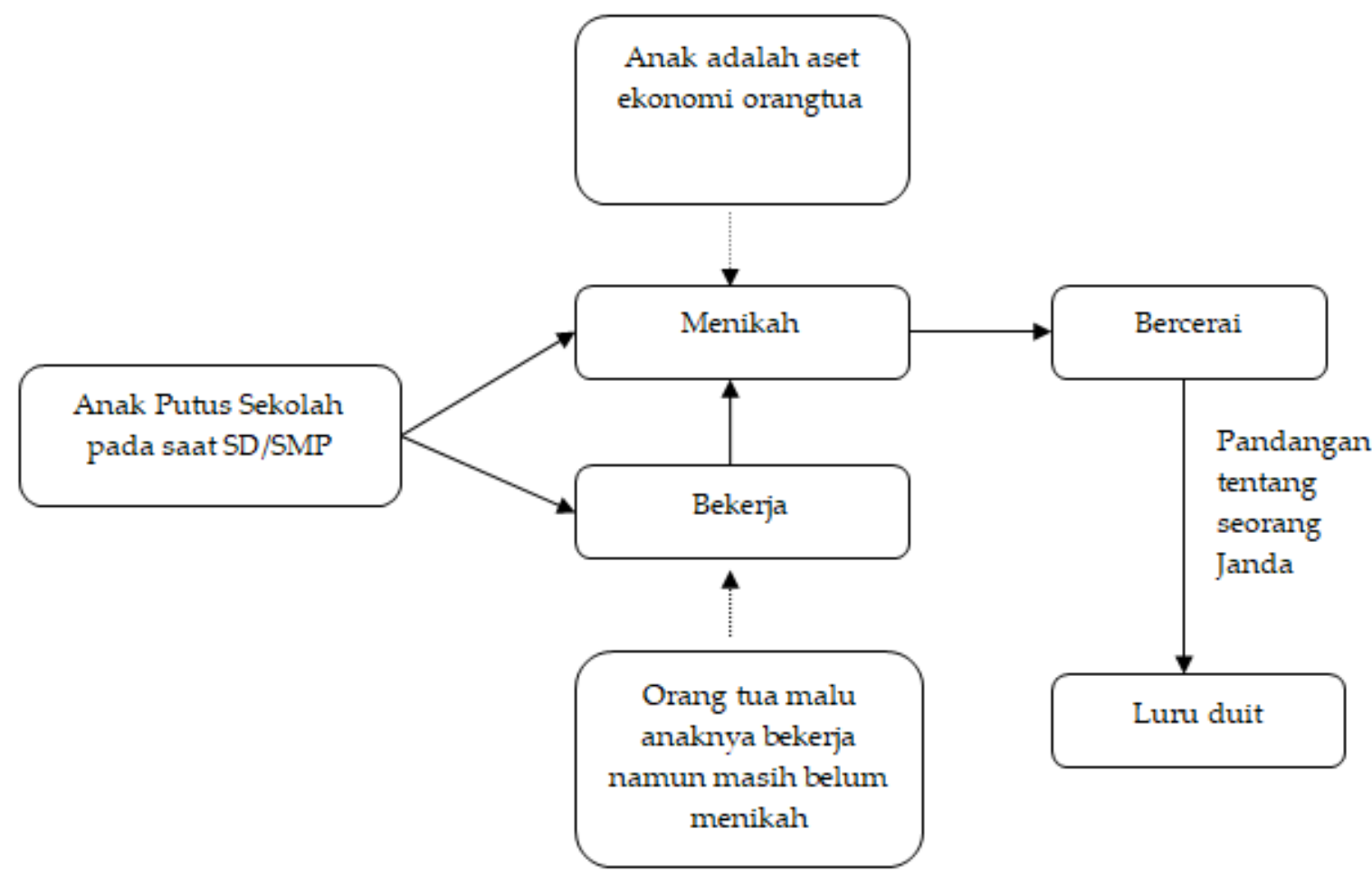

Gambar 2. Alur proses luru duit

Menyandang status janda setelah perceraian merupakan jalur untuk menuju luru duit. Pernikahan anak yang dilakukan di bawah tangan atau nikah kyai seperti pada kasus $\mathrm{Ri}, \mathrm{Na}$, dan $\mathrm{Sa}$ sangat rapuh dan merugikan bagi istri, karena ia tidak memiliki konskeuensi apapun bagi suami terutama pada ekonomi. Seorang janda di masyarakat desa dianggap sebagai beban di dalam keluarganya masing-masing, sehingga mereka dituntut untuk mandiri dan menghasilkan materi untuk keluarga, meskipun masih berusia belia. Keterbatasan keterampilan serta pendidikan mendorong luru duit menjadi pilihan terbaik untuk bertahan hidup.
1. Sosialisasi lingkungan terdekat a. Keluarga

Penelitian ini menemukan bahwa lingkungan terdekat subjek merupakan tepat sosialisasi menuju luru duit. Lingkungan keluarga mensosialisasikan nilai-nilai materialisme pada anak. Orang tua cenderung menafsirkan kebahagiaan hidup dengan kepemilikan materi. Nilai-nilai dan cara pandang orang tua tentang kebendaan diajarkan lewat kudangan, nasehat, serta perintah. Semua hal itu mencerminkan cita -cita dan harapan orangtuanya tentang kebahagiaan. Simbol-simbol kesuksesan tersebut disosialisasikan kepada anak melalui berupa pernak-pernik aksesoris yang dikenakan anak, nama orang 
sukses luru duit, serta tempat/lokasi luru duit.

"Memang diarahkan. Dicantolkan seperti itu. Anaknya pengen sekolah, orang tuanya tanya kenapa harus sekolah? Perempuan itu setinggitingginya sekolah akhirnya megang cowek, kenapa harus sekolah tinggitinggi? Mending kayak Yu Darsiwen. Jadi bukan barang aneh dan barang langka."

Dalam kudangan (lagu untuk menidurkan anak) dengan menyebut nama seseorang yang dianggap sukses dalam luru duit. Sebagai contoh, nama Darsiwen, dikampung itu dianggap tokoh yang sukses kerja di luar kota, maka di dalam kudangan orang tua menyebut nama Darsiwen. Padahal orang sudah tahu semua, Darsiwen bekerja sebagai pekerja seks di Mangga Besar (Mabes), Jakarta. Bisa juga nama Kang Car, meskipun profesinya adalah sebagai germo kaya. Salah satu kudangan yang sering dilagukan untuk menidurkan anak adalah sebagai berikut:

"Blang-ibung iblang iblung

Kage gedhe-kage gedhe

Nak we gedhe neng Arabia

Ngrewangi mimi jare bapak."

(Dalam terjemahan bebas makna yang tersurat dalam lagu kudangan tersebut sebagai berikut: cepat besar anaku, kalau sudah besar berangkat kerja ke Arabia, membantu orang tua.)
Pada akhirnya pendidikan sebagai hak anak bukan menjadi prioritas orang tua karena dikalahkan oleh nilai kesuksesan yang diwujudkan dalam kekayaan. Orang tua cenderung berpendapat menyekolahkan anak adalah hal yang sia-sia, butuh waktu lama dan biaya yang besar. Orang tua tersebut berpandangan anak perempuan sebisa mungkin cepat menghasilkan uang, daripada harus berlama-lama sekolah. Mereka tidak melihat ada manfaatnya seseorang bersekolah tinggi. Lebih baik mereka meniru Yu Darsiwen yang berhasil luru duit.

\section{b. Lingkungan pergaulan sebaya}

Lingkungan sebaya di sekitar subjek di desa Bong merupakan lingkungan yang toleran terhadap aktivitas seks. Orang tua memiliki kecenderungan membiarkan anak perempuanya bergaul dengan temantemannya tanpa kontrol. Tokoh masyarakat setempat menyebutkan bahwa kecenderungan orangtua membiarkan anak perempuan bergaul merupakan bagian dari rencana untuk menuju luru duit. Apabila nantinya mereka mengalami kehamilan tidak dinginkan pada usia remaja, akibatnya mereka akan putus sekolah, dan selanjutnya akan memiliki potensi besar untuk luru duit.

Nah, modus yang sekarang berbeda. Lain lagi. Justru banyak yang kecelakaan, hamil di luar nikah, di kelas dua atau tiga SMP. Nah, terus 
kalau sudah hamil duluan, nah ini kemudian dijadikan alasan untuk anaknya diberangkatkan ke Jakarta. Sudah kepalang tanggung katanya. Jadi, kaya gini ini jadi modus baru buat mereka."

Pergaulan pada teman sebaya ini juga dapat menjadi sebuah media untuk memengaruhi secara pasif gaya hidup modern di kota yang dibawa oleh temannya yang sudah sukses luru duit sebelumnya. Sosok perempuan yang berhasil luru duit akan nampak secara kasat mata dari penampilan hingga aksesoris serta hal lain yang dikenakan. Penampilan yang nampak modern tersebut menimbulkan ketertarikan bagi temannya untuk meniru, kemudian ikut berangkat luru duit. Pada posisi ini, teman sebaya menjadi perantara yang bekerja secara pasif dalam memengaruhi seseorang untuk luru duit.

\section{c. Lingkungan masyarakat}

Sikap yang toleran terhadap aktivitas prostitusi sangat nampak kasat mata di desa Bong. Misalnya, terdapat beberapa warung remang-remang yang biasa disebut kafe, berada di desa tersebut. Kafe ini biasa bentuknya menyerupai warung minum kopi yang di dalamnya dilengkapi fasilitas karaoke dan kamar sederhana. Kafekafe ini sudah lama berada di desa dan tidak pernah mendapatkan penolakan dari warga atau pemerintah. Bahkan, seorang yang mendirikan kafe pertama kali di Bong, justru namanya digunakan untuk nama wilayah, yaitu Blok Tap. Kafe tertua di desa Bong tersebut dikelola oleh cucu-cucu Pak Tap. Tidak ada pelarangan terkait dengan berdirinya kafe tersebut. Hanya saja ada peraturan tidak tertulis yang secara lisan disampaikan pada pengelola untuk mengurangi suara bising. Sehingga, pengelola kafe, seperti Pak Ca yang mengelola kafe di Blok Tap, leluasa menjalankan bisnisnya.

"Jeder-jeder, akhirnya ada. Dari dulu. Awalnya cuma sekitar rumah aja yang kedengaran. Lama-lama, karena soundnya semakin besar-besar ya, alatnya semakin bagus-bagus kan, akhirnya sampai rumah-rumah warga. Makannya dulu lokasi itu buka ya sampai pagi sampai subuh, kalau dulu mah gak ada istilah tutup. Istilahnya ya 24 jam. Karena ya itu tadi, kalau dulu mah gak ada musik cuma sekedar melayani tamu yang mencari kepuasan aja. Tahun 80an lah. Tahun 90an sudah pakai musik trus akhirnya diperketat waktunya dari 24 jam sampai jam 12 malam udah tutup. Itu aja.

Selain itu, terdapat sikap umum yang muncul pada masyarakat manakala seseorang tersebut berhasil dalam luru duit. Keberhasilankeberhasilan yang diwujudkan bentuk materi ini menjadi pusat perhatian di masyarakat Bong. Sikap yang "dermawan" pada warga akan 
mengubah pandangan warga terhadap mereka. Tetangga menjadi segan dan mengakui keberhasilan mereka.

Pada saat mereka berangkat bukan apa-apa, kini setelah sukses mereka menjadi bahan perbincangan. Hal seperti itu memunculkan rasa bangga pada diri mereka yang berhasil luru duit. Karena ketika banyak yang mendekat pada dirinya, mereka merasa dibutuhkan di masyarakat. Situasi seperti ini yang mendorong warga Bong memiliki pandangan yang positif terhadap luru duit. Luru duit akhirnya dapat diterima sebagai bagian dari masyarakat Bong. Seperti pengalaman Ri, yang cukup berhasil ketika bekerja di Hotel M, Jakarta.

"Gak (cuma) muji. Orang malah jadi segan. Jadi orang tu pada mikir, "Oh ya ternyata ada hasilnya seperti ini". Contohnya ya pujianya ya bagus aja, Waa.. sekarang sudah ada pembuktianya. Kalau dulu kan gak, Waa..usahanya udah seperti ini seperti ini."

Lingkungan masyarakat yang toleran terhadap aktivitas prostitusi serta ditambah lagi sikap positif terhadap keberhasilan perempuan yang luru duit semakin melanggengkan kebiasaan tersebut. Tidak ada sanksi sosial yang muncul, kebiasaan luru duit itu justru mendapatkan dukungan dari masyarakat.

\section{Diskusi}

Fenomena luru duit secara sukarela, sebagai sebuah perilaku yang sudah terencana. Mereka yang melakukan luru duit sesungguhnya sudah merencanakan sejak awal. Baik orang tua, anak perempuan dan masyarakat memiliki peran dalam membentuk kebiasaan luru duit di desa tersebut. Bandura (1989) dan Ajzen (1991) mengatakan pada dasarnya seseorang melakukan perilaku dengan cara-cara yang masuk akal. Individu mempertimbangkan semua informasi yang ada. Selain itu, resiko-resiko yang mungkin terjadi akibat perilaku tersebut juga sudah dipertimbangkan. Perilaku terbentuk dengan adanya faktor eksternal dan internal dari individu yang bersangkutan.

Mengacu pada Teori Perilaku Berencana (TPB), dapat diuraikan tiga faktor utama yang mempengaruhi seseorang memilih menjadi pelaku luru duit, yaitu faktor personal yang memicu luru duit, faktor lingkungan yang mendukung luru duit serta adanya pengaruh dari perantara (channel) yang mempermudah proses luru duit.

\section{Faktor Personal Pendorong Luru duit}

Ada beberapa faktor personal yang mendorong berlangsungnya praktek luru duit. Di antaranya adalah sikap materialisme hidup dalam kesugihan menguatkan sikap positif terhadap luru duit. 
Sikap merupakan hasil dari sebuah penilaian tentang harapan yang diinginkan pada sebuah perilaku. Sifat positif atau negatif sebuah sikap yang terbentuk tergantung pada behavioral belief, yaitu hal-hal yang diyakini oleh individu mengenai sebuah perilaku dari segi positif dan negatif. Hal ini merupakan sebuah penilaian tentang hasil yang diharapkan pada sebuah perilaku (Azjen, 1991).

Pada konteks prostitusi, keyakinan perilaku ini bisa digambarkan sebagai harapan untuk memiliki hidup mewah, memiliki barang mahal, atau rumah mewah (Cimino, 2013). Mengacu pada Koentjoro (2004), Pattilima (2005) dan Suyanto (2012), tujuan seseorang terjun ke dalam prostitusi karena mereka didorong oleh aspirasi materiil. Tujuan orang agar anaknya luru duit sematamata karena dorongan materialisme. Dengan memiliki memiliki harta akan meningkatkan status sosial, dan memberikan kebanggaan di mata komunitas masyarakat. Dalam kosakata bahasa Indonesia, sugih diartikan sebagai kaya, memiliki harta yang melimpah. Keinginan untuk hidup sugih ini pada akhirnya mendorong orang tua menggunakan kuasanya untuk membujuk, merayu ataupun memaksa anaknya agar luru duit. Mereka adalah orang yang diuntungkan secara materi apabila anak luru duit.

Jauh sebelum masa sekarang, sesungguhnya praktik luru duit tidak berbeda dengan praktik perseliran di masa kerajaan. Orang tua termotivasi untuk menjadikan anaknya sebagai selir-selir raja untuk meningkatkan status sosial. Pada posisi tersebut, anak perempuan menjadi komoditas yang dipertukarkan. Saat ini, pola pertukaran anak perempuan sebagai komoditas ini berulang berganti rupa menjadi luru duit.

Hal ini semakin memperjelas bahwa luru duit merupakan praktik eksploitasi anak untuk kepentingan ekonomi orang tua. Imelda (2004) dengan tegas menyebutkan bahwa prostitusi anak merupakan suatu tindakan eksploitatif terhadap anak untuk kompensasi dalam bentuk uang ataupun dalam bentuk barang. Eksploitasi seksual anak merupakan bagian dari motif perdagangan anak.

Kepatuhan anak sebagai norma subjektif

Norma subjektif adalah sejauhmana seseorang memiliki motivasi untuk mengikuti pandangan orang lain terhadap perilaku yang akan dilakukan. Orang tua merupakan salah satu sumber referensi bagi seorang anak dalam pengambilan keputusan melakukan luru duit. Sebagai anak, mereka harus patuh serta tidak boleh melawan pada kehendak orang tua. Keputusan untuk berhenti sekolah, dinikahkan, serta berangkat luru duit merupakan bentuk sikap kepatuhan guna memenuhi harapan orangtua 
untuk hidup sejahtera. Karena alasan kemiskinan mendorong orang tua Sa memutuskan sekolahnya semenjak SD, serta menikahkan dengan seorang yang jauh lebih tua.

Menurut Rosenberg (2003), maraknya anak perempuan putus sekolah atau hanya menyelesaikan pendidikan di tingkat SMP dikarenakan adanya cara pandang umum yang masih permisif terhadap anak-putus sekolah. Anak-anak yang putus sekolah dan bekerja bekerja dalam lingkungan masyarakat di sekitar Sa bukan sesuatu yang asing lagi. Hal ini sudah dianggap lumrah, diterima dan memang sudah seharusnya. Karena dalam usia tersebut mereka telah layak bekerja. Di daerah pengiriman dan jaringan perdagangan anak, menyebutkan umumnya masyarakat telah menganggap anak yang menamatkan sekolah dasar mereka telah dianggap cukup usia untuk memikul beban tanggung jawab ekonomi keluarga.

Cara pandang tentang peran dan tanggung jawab ekonomi keluarga, merupakan sebuah konteks budaya setempat yang tidak berpihak pada anak-anak perempuan. Kepatuhan yang harus dilakukan oleh anak-anak untuk memenuhi harapan sebagai tulang punggung orangtua, mendorong mereka untuk bekerja di usia muda. Situasi seperti itu yang menutup akses anak perempuan untuk mendapatkan pendidikan sebagai modal untuk meningkatkan kualitas hidupnya. Seharusnya, melalui pendidikan mereka akan memliki kapasitas keterampilan yang cukup sehingga mampu mendapatkan kesempatan kerja yang luas. Adanya kesempatan kerja yang luas ini akan semakin menekan peluang mereka untuk melakukan luru duit.

Wismayanti (2010) menyatakan akan adanya anggapan bahwa anak memiliki peran dan tanggung jawab, merupakan sebuah konteks budaya yang mendorong anak-anak terlibat dalam pekerjaan produktif bagi keluarganya. Beban orangtua, kemiskinan, serta nilai-nilai kepatuhan yang harus dilakukan oleh anak-anak terhadap orangtua sebagai balas jasa, mendorong mereka untuk bekerja pada usia muda. Iming-iming pekerjaan di kota yang lebih menjanjikan, daripada sekedar mengandalkan orangtuanya yang hanya buruh tani di daerah asalnya, juga mendorong anak-anak melakukan urbanisasi.

Budaya dan nilai-nilai yang dianut oleh masyarakat merupakan salah satu faktor pembentuk munculnya daerahdaerah pengirim perempuan untuk dilacurkan. Suyanto (2012) menegaskan bahwa pelibatan anak untuk dilacurkan terjadi karena adanya ketidakberdayaan menghadapi lingkungan yang tidak berpihak kepada anak, yaitu kurangnya pendidikan, lingkungan sosial yang asimetris, struktur sosial yang memarginalisasi dan lebih banyak 
didominasi ideologi patriarkhis. Sementara itu, pengaruh lingkungan eksternal untuk melacurkan anak muncul dari adanya nilai sosial budaya yang dianut masyarakat.

Di kawasan Asia, nilai-nilai budaya yang hidup di masyarakat kerap kali menjadi faktor pendorong anak untuk dilacurkan. ECPAT (2008); Romanow (2012) dan Tumlin (2000), menemukan bahwa prostitusi anak di Thailand dan Vietnam berkembang karena di dorong oleh budaya lokal, terutama terkait nilai-nilai dan harapan orang tua pada seorang anak perempuan sebagai penopang tanggung jawab ekonomi keluarga. Medora (2011) menyebutkan bahwa di India masih terdapat praktik budaya devadasi, dimana orang tua dengan sukarela menyerahkan anak perempuanya untuk dijadikan "pelacur dewa". Tradisi devadasi di India mengharuskan seseorang perempuan dalam kasta tertentu harus menjadi pelacur dewa. Devadasi sendiri berarti sebuah persembahan kepada Dewa.

Peran Model, Channel, dan Dukun Menguatkan Persepsi Kemudahan Luru Duit

Dibandingkan dengan bentuk pekerjaan lain, luru duit dianggap yang paling mudah untuk dilakukan serta paling cepat mendatangkan hasil. Karena ia tidak memerlukan ketrampilan ataupun kompetensi khusus untuk melakukanya. Pandangan tersebut yang seterusnya menjadi keyakinan bagi para pelakunya bahwa dirinya mampu melakukan dan mendapatkan jaminan keberhasilan. Sehubungan dengan itu, Azjen (1991) menyebutkan bahwa persepsi atas kontrol perilaku memiliki konsep yang sama dengan self efficacy, yaitu penilaian kemampuan diri untuk melaksanakan sebuah kinerja pada tingkat tertentu. Hal ini diperoleh dari pengalaman yang diperoleh melalui orang lain, pengetahuan, peluang kesempatan atau waktu untuk melakukanya, adanya fasilitas dan memiliki kemampuan diri untuk menghadapi kesulitan dalam pelaksanaannya.

Dalam konteks luru duit, terdapat beberapa sumber yang dapat meningkatkan keyakinan atas perilaku yang akan dilakukan. Pertama, adanya role model perempuan muda sebaya mereka yang telah sukses/ berhasil luru duit. Keberhasilan tersebut ditandai dengan citra diri dengan gaya hidup kekinian (modern) serta peningkatan ekonomi keluarganya di desa. Selanjutnya, munculnya perantara yang biasa disebut sebagai channel yang menyediakan fasilitas serta mengatur keberangkatan. Selain itu, untuk mengatasi hambatan dan kesulitan dalam persaingan di tempat kerjanya, peran dukun menjadi penting. Biasanya, menjelang keberangkatan, persiapan yang dilakukan para pelaku luru duit adalah dengan meminta jampi-jampi agar nantinya laris mendapatkan tamu 
banyak. Biasanya mereka akan diberikan bedak dan air yang sudah diberi jampi penglaris. Bekal dari dukun itu memberikan keyakinan bagi mereka yang luru duit akan mampu mengatasi kesulitan, persaingan serta antisipasi kegagalan.

\section{Faktor Lingkungan Yang Kondusif}

Sosialisasi Materialisme Dalam Keluarga

Pola asuh anak dalam keluarga yang tidak sehat memperbesar potensi kerentanan anak untuk masuk prostitusi. Lung (2003) menunjukan bahwa keluarga yang disfungsional serta pola asuh yang cenderung negatif mempunyai kontribusi pada potensi remaja untuk terlibat dalam prostitusi. Lebih lanjut, ia mengatakan bahwa sebagian besar remaja yang terlibat dalam prostitusi memiliki ketergantungan emosional dan lebih menyandarkan penilaian diri mereka pada opini dan pendapat orang lain.

Keluarga memiliki peran penting dalam mensosialisasikan nilai-nilai kepada anaknya. Keluarga adalah sebuah lembaga penting dalam masyarakat yang merupakan kelompok pertama dalam kehidupan manusia, tempat seseorang melakukan proses pembelajaran dan menyatakan diri sebagai manusia di dalam hubungan interaksi dengan kelompoknya. Keluarga memiliki peran dominan dalam membentuk individu melalui pembelajaran dan penyesuaian diri, untuk memiliki pandangan, tindakan serta perilaku dan sikap di masyarakat.

Menurut Kasser (2002) sistem nilai yang tumbuh dalam diri anak berkembang melalui imitasi kepada orang tua mereka. Lebih lanjut, sosialisasi materialisme pada anak melibatkan perilaku yang spesifik pada orang tua yang memperkuat nilai materialisme pada anak. Orang tua dalam mensosialisasikan nilai materialismenya sering kali menggunakan pesan-pesan yang implisit terhadap anaknya bahwa nilai kemakmuran dan status merupakan hal yang utama.

Sosialisasi nilai materialisme ini tampak dalam keseharian di kampung "Tap", dimana anak-anak sejak kecil sudah diperkenalkan dengan negeri Taiwan sebagai tempat untuk bekerja. Anak-anak ditanamkan pemahaman bahwa suatu saat apabila kerja di Taiwan sukses dan menghasilkan banyak uang. Orang tua meyakini di Taiwan dapat sukses dan mengangkat ekonomi keluarga. Negara Taiwan dan Arab Saudi merupakan dua di antara beberapa negara yang menjadi lokasi tujuan perempuan bekerja yang menjanjikan keberhasilan dan kesuksesan. Cerita-cerita seperti itu sering muncul disampaikan ketika orang tua sedang menimang anak mereka sebagi pengantar tidur.

Berkaitan dengan hubungan dengan orang lain, seorang yang 
materialistik akan memandang orang di sekitarnya adalah sebagai objek. Bagi mereka, pengalaman subjektif dan perasaan dengan orang lain bukan menjadi hal yang pokok atau dengan kata lain dipandang berguna atau tidak bagi dirinya. Tidak berbeda dengan sebuah barang, dipakai ketika berguna atau dibuang ketika sudah tidak berguna (Kasser, 2002). Anak-anak dipandang sebagai komoditas yang dipertukarkan dengan sejumlah uang bagi orang tua. Cara pandang seperti itu disosialisasikan sejak masa kanakkanak, sehingga ketika mereka beranjak remaja nilai tersebut yang dianut. Cara pandang seperti mengakibatkan pendidikan bagi anak bukanlah prioritas di dalam lingkungan keluarga. Pada orang tua ini memiliki pandangan percuma anak perempuan sekolah tinggi, karena pada akhirnya mereka juga hanya menjadi ibu rumah tangga, melayani suami dan mengurus anak. Lebih baik seperti Yu Darsiwen, yang putus sekolah, tapi bisa menghasilkan banyak uang melalui luru duit.

Grace (2012) menyebutkan bahwa keterlibatan anak dalam prostitusi tidak bisa didasarkan pada sebuah pilhan dalam merespon kondisi ekonomi dan keterbatasan ruang serta peluang kerja. Karena pada usia perkembangan anak dan remaja mereka belum layak untuk bekerja serta belum memiliki kematangan psikis maupun fisik. Pelibatan anak dalam prostitusi harus dilihat dalam relasi kuasa antara orang dewasa terhadap anak-anak.

\section{Nilai Anak Bagi Orang Tua}

Di Indonesia, menurut Jones dan Gubhaju, (2008) perkawinan anak merefleksikan sebuah penikahan yang diatur atau sebagai respon terhadap kehamilan yang tidak direncanakan. Temuan sama terdapat dalam studi yang dilakukan Aminullah (2012) tentang pernikahan dini pada lima provinsi, Jawa Barat salah satunya. Menyatakan bahwa terjadinya 'pemaksaan' pernikahan atau perjodohan remaja oleh orangtua yang berasal dari kalangan ekonomi lemah karena alasan bahwa pernikahan dapat mengurangi beban tanggungan ekonomi keluarga dan menyejahterakan anak yang dinikahkan.

Setelah mereka bercerai atau ditinggalkan suaminya mereka kemudian melakukan luru duit. Hal ini menunjukan adanya pola keterkaitan antara pernikahan dan perceraian dengan luru duit. Pada saat mereka kembali keluarga mereka dianggap menjadi beban di dalam keluarganya masing-masing. Sehingga dituntut untuk mandiri dan menghasilkan materi untuk keluarga meskipun masih berusia belia. Di samping itu, dengan kapasitas keterampilan serta pendidikan yang rendah menyebabkan terbatasnya pilihan untuk bekerja. Sehingga jalan pintas luru duit diambil 
sebagai pilihan yang rasional meskipun secara terpaksa.

Hasil studi menyebutkan bahwa terjadinya perkawinan pada anak usia dini akan membuka jalur menuju prostitusi. Qayyum (2013) menyebut perkawinan anak meningkatkan kerentanan pada prostitusi. Selain itu, perkawinan anak berdampak baik secara fisik sosial maupun ekonomi seorang anak (Birech, 2013). Mikhail (2002) mengemukakan perkawinan anak dan prostitusi memiliki kesamaan, yaitu adanya transaksi ekonomi serta perampasan kebebasan terhadap anak serta adanya pelanggaran hak persetujuan. Dampaknya adalah anakanak rentan terhadap akses ekonomi dengan sedikitnya pilihan yang terbuka serta munculnya kerentanan sosial.

Orang tua yang melacurkan anaknya menilai anak perempuan mereka pada sisi ekonomi, yaitu agar sesegera mungkin menghasilkan uang serta berkontribusi bagi orang tuanya. Nilai anak/value of children (VOC) dipahami sebagai pencerminan motivasi orangtua untuk menanggung dan membesarkan anak. Motivasi yang dimaksud mengandung tujuan pribadi dan sosialisasi dari pengalaman orangtua itu sendiri. Jika dikonseptualisasikan, nilai anak lebih sebagai konstruk psikologis yang mengacu pada manfaat yang diharapkan dari kepemilikan anak dibanding dengan biaya dan kerugian yang dikeluarkan (Bulatao, 1975).

Sikap Positif Masyarakat dan Kontrol sosial rendah

Kontrol Sosial adalah kapasitas sebuah kelompok masyarakat untuk mengatur kelompok mereka sendiri (Janovits, 1975). Pemerintah Daerah Indramayu telah menerbitkan Peraturan Daerah No 7 tahun 1999 tentang prostitusi dan disempurnakan pada tahun 2001, yang berisi tentang larangan praktik-praktik prostitusi di Indramayu. Selain itu, terdapat juga perda anti miras No 7 tahun 2005 dan diubah pada tahun 2006.

Beberapa Peraturan tersebut diterbitkan sebagai usaha untuk menekan pertumbuhan prostitusi baik yang terbuka di warung karaoke, lokasi-lokasi di kampung maupun yang tertutup di hotel-hotel melalui razia dan operasi tindak pidana ringan. Namun yang terjadi justru sebaliknya. Pertumbuhan prostitusi di Indramayu tumbuh dengan pesat. Baik di kota maupun di pelosok desa, lokasi untuk mendapatkan layanan seksual (jajan) dapat ditemui di berbagai sudut di Indramayu.

Keterlibatan oknum aparat Negara juga merupakan indikasi bahwa terjadi penyimpangan dalam tugasnya. Fenomena totot sewu (kode patroli aparat di lokalisasi untuk minta jatah uang) adalah bukti pelanggaran kode 
etik aparat yang justru mengambil keuntungan dari adanya bisnis prostitusi. Tidak menutup kemungkinan, keterlibatan aparat hanya sebatas kongkalikong totot sewu dengan para penglola kafe lokal saja. Fenomena totot sewu merupakan salah satu bentuk penyimpangan peran dari aparat keamanan negara. Situasi lingkungan sosial seperti ini mirip seperti yang disebut Durkheim sebagai anomie, yaitu kondisi tanpa aturan, dimana aturan-aturan yang ada sudah kehilangan makna dan tidak berfungsi pada banyak orang (dalam Hilbert, 1986).

Role Model Channel sebagai Perantara Yang Mempermudah Proses Luru Duit

Koentjoro (1998) menjelasakan fungsi perantara dalam bisnis prostitusi adalah sebagai pencipta persediaaan dan penjaga persediaan dalam industri seks. Mereka akan secara pasif memengaruhi dengan cara menceritakan keberhasilan para pekerja seks sebelumnya. Mereka juga secara aktif melakukan bujuk rayu kepada orangtua dan perempuan yang potensial untuk mau dipekerjakan.

Di desa-desa, terutama di desa Bong, sosok perantara ini dikenal sebagai Channel. Channel adalah orang kepercayaan seorang germo atau mucikari yang ditugaskan untuk menyediakan perempuan-perempuan baru yang bersedia luru duit. Channel berperan dalam mencari serta mensponsori keberangkatan seorang anak untuk luru duit. Dukungan finansial yang diberikan oleh germo berupa uang tunai (kasbon) untuk orang tua. Kasbon merupakan uang yang dibebankan kepada anak untuk kemudian harus dikembalikan melalui luru duit. Bagi channel aktif, imingiming dukungan finansial kasbon ini merupakan penguat (reinforcement) agar orang tua ataupun anak mau untuk melakukan luru duit.

Channel merupakan sosok yang dikenal. Sosok ini bisa diperankan oleh tetangga atau seorang yang telah luru duit sebelumnya. Sosok perempuan yang luru duit dapat secara pasif maupun aktif mempengaruhi orang tua, maupun anak, untuk luru duit. Bagi orang-orang di sekitar mereka, sosok yang telah sukses akan menjadi panutan bagi mereka. Hal ini dapat dipahami sebagai sebuah proses belajar sosial dimana peran model sangat penting untuk ditiru. Kehadiran sosok model seperti para pekerja seks yang pulang kampung merupakan bagian penting dari sebuah observational learning. Sebagian besar perilaku yang ditampilkan seseorang, dipelajari baik secara bebas maupun dengan kehati-hatian melalui pengaruh sebuah model (Bandura, 1989).

\section{Kesimpulan}

Penelitian ini telah mengidentifikasi faktor-faktor yang mempengaruhi perkembangan luru duit di Indramayu. Faktor-faktor tersebut antara lain faktor permintaan yang memicu luru duit, faktor persediaan yang berperan mendorong serta menjadi lahan subur perkembangan 
luru duit serta adanya faktor perantara yang menjadi fasilitator antara permintaan di kota dan persediaan di desa. Faktor permintaan sebagai pemicu sangat terkait dengan pertumbuhan ekonomi yang memunculkan kota-kota surga bagi penikmat seks anak. Selain itu, mobilitas pekerja di Indramayu menjadi pemicu adanya permintaan seks anak di Indramayu. Selanjutnya, branding RCTI untuk perempuan Indramayu merupakan bagian dari strategi marketing germo yang memperkuat mitos-mitos seks dengan anak.

Luru duit tidak hanya dipicu oleh permintaan, akan tetapi juga didorong oleh faktor internal, yaitu motif yang memengaruhi sikap positif terhadap luru duit serta adanya lingkungan sosial yang menyuburkan praktik luru duit tersebut. Aspirasi materialisme, yaitu keinginan untuk hidup kaya merupakan penyebab orang tua rela membujuk atau memaksa anaknya untuk melakukan luru duit. Sementara itu, hasrat konsumerisme pada anakanak sebagai akibat dari modeling sebaya di sekeliling menyebabkan mereka secara sadar dan sukarela melakukan luru duit. Hal lainnya, terdapat faktor kemiskinan struktural disebabkan adanya cara pandang yang melemahkan perempuan sehingga mereka akhirnya tidak mampu untuk mengakses peluang dan kesempatan. Hal ini menjadikan luru duit sebagai strategi untuk bertahan hidup. Selanjutnya, faktor lingkungan terdekat yang menyuburkan luru duit adalah lingkungan keluarga melalui sosialisasi materialisme, tekanan lingkungan sebaya melalui modeling, adanya dukungan sosial melalui praktik pernikahan anak, serta kontrol sosial yang lemah.

Fenomena luru duit semakin dimudahkan oleh adaya sosok channel, yang kehadiranya berperan sebagai penghubung antara korban dengan pemilik modal. Sosok penghubung ini beroperasi dalam dua cara. Cara pertama adalah dengan kekerasaan, paksaan serta penipuan, sementara untuk cara yang kedua adalah dengan memanfaatkan keinginan korban dan orangtua korban untuk hidup lebih baik dengan cara merayu, mengiming-imingi uang yang besar dan lainnya. Sosok perantara dapat diperankan oleh orangtua korban sendiri yang secara aktif menawarkan anaknya kepada channel, seorang yang sudah pernah luru duit atau mantan yang sedang pulang kampung yang berperan sebagai channel yang akan membawa korban kepada bos mereka di kota. Yang terakhir adalah seorang channel, yang ditugaskan oleh germo, yang secara aktif bergerilya mencari korban di desa.

\section{Daftar Pustaka}

Ajzen, I. (1991). Organizational Behavior And Human Decision Processes. 
University of Massachusetts: Academic Press, Inc.

Bandura, A. (1989). Social cognitive theory. In R. Vasta (Ed.). Greenwich, CT: JAI Press.

Birech, J. (2013). Marriage: A cultural health phenomenon. International Journal of Humanities and Social Science. 3 (17). (97-103).

Bulatao, R. A. (1975). The value of children: Across national study. Hawaii: East West Population Institute.

Budi. (2015). Kabupaten Indramayu jadi penyuplai terbanyak di Saritem. Diakses di http://fokusjabar.co.id (tanggal \& Januari 2017)

End Child Prostitution, Child Pornography and Trafficking of Children for Sexual Purposes (ECPAT). (2008). Memerangi Pariwisata Sex Anak: Tanya Jawab. Bangkok: ECPAT.

Grace, G. L., Starck, M., Potenza, J., \& Sheetz, H. A. (2012). Commercial sexual exploitation of children and the school nurse. The Journal of School Nursing. 28 (6), 410-417.

Hilbert. R. A. (1986). Anomie and the moral regulation of reality: the durkheimian tradition inmodern relief. Sociological Theory, 4(1), 1-19.

Hirschi, T. (1969). A Control theory of delinquency. Reprinted from Causes of Delinquency. California: University of California Press.

Hwang, S. L., \& Bedford, O. (2003). Precursors and pathways to adolescent prostitution in Taiwan. The Journal of Sex Research, 40 (2).

International Labour Organization. (ILO). (2004). Perdagangan anak untuk tujuan pelacuran di Jakarta dan Jawa Barat: Sebuah kajian cepat. Geneva Switzerland. Bureau International Labour Office.

International Labour Organization. (ILO). (2005). Guidelines for legislation and law enforcement: Special action programme to combat forced labour. Geneva : Bureau International Labour Office.

Imelda, Debora, J. Marthini, T., \& Setyawati, L. (2004). Utang selilit pinggang: System ijon dalam perdagangan anak perempuan. Yogyakarta : Pusat Studi Kependudukan dan Kebijakan Universitas Gadjah Mada.

Jones. G.W. dkk. (1994). Divorce in West Java. Journal of Comparative Family Studies, 25(3) 395-416.

Kasser, T. (2002). The high price of materialism A Bradford Book. London : The MIT Press.

Koentjoro. (1998). Pelacur anak - anak dan jaringanya : Studi kasus di Yogyakarta. Semiloka Nasional Prostitusi Anak Dan Industry Pariwisata, diselenggarakan Oleh Pusat Penelitian Pengembangan Pariwisata UGM, ILO di Yogyakarta tanggal 1-2 Juli 1998.

Koentjoro. (2004). On the spot: Report from the nest of prostitutes. Yogyakarta: Tinta.

Koentjoro, \& Fitriana, N. (2011). Prostitution in Indonesia. Dalam Dalla, R. L., Baker, L. M., DeFrain, J., \& 
Williamson, C. (Eds.) (2011), Global Perspectives on Prostitution and Sex Trafficking: Africa, Middle East, Asia, \& Oceania. Landham, MD: Lexington Publishers, Inc.

Kusumawardhani. (2010). Human trafficking: Pola pencegahan dan penanggulangan terpadu terhadap perdagangan perempuan: laporan akhir penelitian (Laporan penelitian tahun II: studi kasus pola pencegahan dan penanggulangan terpadu terhadap perdagangan perempuan di Propinsi Jawa Barat. Laporan Penelitian. Pusat Penelitian Kemasyarakatan Dan Kebudayaan Lembaga Ilmu Pengetahuan Indonesia PMB- LIPI, Jakarta.

Lung. W., Lin T.J., Ching. L. Y., Shu. C. B, (2004). Personal characteristics of adolescent prostitutes and rearing attitudes of their parents: A structural equation model. Psychiatry Research, 125. 285-291.

Medora, N. (2011). Prostitution in India: A global problem. Dalam Dalla, R. L., Baker, L. M., DeFrain, J., \& Williamson, C. (Eds.) (2011), Global Perspectives on Prostitution and Sex Trafficking: Africa, Middle East, Asia, \& Oceania. Landham, MD: Lexington Publishers, Inc.

Muflichah. S. (2009). Trafficking: Suatu studi tentang perdagangan perempuan dari aspek budaya, sosial, ekonomi di kabupaten Banyumas. Jurnal Dinamika Hukum. 9(1), 125-134.

Pattilima, H. (2005). Perdagangan anak: Kasus Indramayu. Semiloka Nasional Upaya Penghapusan Trafiking Perempuan dan Anak. Hotel Salak Bogor, Jawa Barat 19-21 Desember 2015.

Rosenberg, R. (2003). Perdagangan perempuan dan anak di Indonesia. Jakarta : USAID bekerjasama dengan ICMC dan ACILS.

Soares, J. R. (2011). Meraba realitas pelacuran anak: Antara mengadili dan mencari solusi. Buletin Makna, Volume 1.

Stoebenau, K. (2008). The "prostitute" and "sex worker" identities in Antananarivo, Madagascar. International Journal of Feminist Approaches to Bioethic. 2(1) 102-120.

Suyanto, B. (2002). Perdaganganan anak perempuan: Kekerasan seksual dan gagasan kebijakan.Yogyakarta : Ford foundation dan PSKK UGM.

Suyanto, B. (2012). Kisah tragis anak perempuan di industri seksual komersial. Jurnal Masyarakat, Kebudayaan dan Politik. 25(3), 163-173.

Suyanto, B. (2013). Child trafficking dan industri seks global. Global $\mathcal{E}$ Strategis, 7(1), 139-154.

Tumlin, K.C. (2000). Trafficking in children and women in Asia : A regional overview. Maklah. Paper presented di forum ILO-IPEC dan Institute for Asian Studies Chulangkorn University, Bangkok.

Komisi Perlindungan Anak Indonesia (2001). Undang-Undang No 23 tahun 2002 Tentang Perlindungan Anak. Diunduh dari www.kpai.go.id. 
Undang-Undang Republik Indonesia No 21 tahun 2007 tentang Tindak Pidana Perdagangan Orang. Diunduh dari pih.kemlu.go.id

Uchrowi, Z. (2003), Menggagas renaissance Indonesia: Refleksi kebangsaan seorang muslim. Republika: Jakarta.

United Nation of Childrens Fund (UNICEF). (2001). Children on the edge protecting children from sexual exploitation and trafficking in East Asia and the Pacific. UNICEF East Asia and Pacific Regional Office.

United Nation of Childrens Fund (UNICEF). (2012). Child maltreatment: prevalence, incidence and consequences in the East Asia and Pacific region: A systematic review of research strengthening child protection systems series: No 1, UNICEF East Asia and Pacific Regional Office.
Qayyum, S., Iqbal, M.M.A, Akhtar, A., Hayat, A., Janjua, I.M., \& Tabassum. S. (2013). Causes and decision of women's involvement into prostitution and its consequences in punjab, Pakistan. Academic Research International. 4(5), 398411.

Romanow, L. (2012). The women of thailand. Global Majority E-Journal. 3(1). 44-60.

Wibowo $_{\iota}$ E.A. (2014). Kisah Wanita Penghibur Di Batam Ogah Layani Lelaki India. Diakses di https://www.merdeka.com (Tanggal 7 Januari 2018).

Wismayanti, Y. F. (2012). Perempuan dalam jaringan perdagangan anak yang dilacurkan di kota Surabaya, Jurnal Sosiokonsepsia. 17(02), 117-133. 